Elsevier Science Publishers B.V., Amsterdam - Printed in The Netherlands

\title{
RECENT INNOVATIONS IN CULTIVATION OF EDIBLE MOLLUSCS IN TAIWAN, WITH SPECIAL REFERENCE TO THE SMALL ABALONE HALIOTIS DIVERSICOLOR AND THE HARD CLAM MERETRIX LUSORIA
}

\author{
HON-CHENG CHEN \\ Department of Zoology and Institute of Fishery Biology, National Taiwan University, Taipei, \\ Taiwan.
}

\begin{abstract}
Chen, H.-C., 1984. Recent innovations in cultivation of edible molluses in Taiwan, with special reference to the smali abalone Haliotis diversicolor and the hard clam Meretrix husoria. Aquaculture, 39: 11-27.

Annual production and culture area of small abalones and hard clams have surprisingly increased in recent years. The factors contributing to this increase, aside from heavy demand and high price, include new techniques in catching the tiny clam seed $(0.5 \mathrm{~mm}$ in size), success in mass production of seed of both species in hatcheries, better understanding of the molluscs' biology as well as their response to environmental changes, improved management of water quality to provide the optimal growth conditions, cheap and easy supply of Gracilaria for abalone feed, use of powdered formulated feed for hard clams, application of chicken manure and rice bran to enrich the water, intermediate harvest of animals of marketable size, and control of predators. However, major constraints to further development and expansion of mollusc cultivation remain, including water pollution from industrial wastes, limited area with suitable water supply, strict regulations on the use of seashore land and littoral zone, and the lack of export market.

Other species of molluscs, including the oyster Crassastrea gigas, the short-necked clam Comphina veneriforms, the purple clam Soletellina diphos, the cockle Anadara granosa, and the small freshwater clam Corbicula, have potential for further expansion if problems of seed supply, water pollution, control of disease, and market price are properly solved.
\end{abstract}

\section{INTRODUCTION}

Total annual production of molluscs in Taiwan has rapidly increased from 12,519 metric tons in 1965 , to an estimate of 50,693 metric tons in 1982 . The production is extraordinary, in view of the small available culture area in Taiwan. Most of the production areas are situated in estuaries, tidal land, and shallow sea, and therefore do not have to compete with agriculture for land use. Of the total molluscan production, about $93 \%$ comes from aquaculture, and the remainder from natural waters.

More than 13 species of molluscs have been successfully cultured on about 19,000 hectares. These include oysters, hard clams, short-necked clams, small 
abalones, and freshwater Corbicula. Oyster culture leads in both production and area farmed; about 11,500 hectares are devoted to this species. It is followed by the farming of hard clams and short-necked clams, with an area of 5,610 hectares. Freshwater Corbicula is also an important species, with a total culture area of 1,810 hectares. The rest of the areas are used for culture of the remaining species (Taiwan Fisheries Bureau, 1982).

Although oysters are the most important species farmed, total oyster production increases only gradually. On the contrary, production of hard clams, short-necked clams, small abalones and freshwater Corbicula has increased sharply in recent years. Their rapid development is due to recent innovations, among other reasons. Therefore, the present study places special emphasis on the description of culture innovations of these species, such as collection of tiny clam seed from the wild, mass production of abalone and hard clam seed in hatcheries, year-round seed reproduction of freshwater Corbicula in ponds, and development of harvesting methods.

On the other hand, problems such as the mass mortality of clams and oysters caused by predators and water pollution (Jeng and Chen, 1975), short supply of seed of certain luxury species, and strict government control on the use of rocky shore areas remain unsolved and seriously restrain further development of molluscan aquaculture. In addition, the price of molluscs in the local market is high, making it difficult to develop an export market.

\section{SMALL ABALONE, HALIOTIS DIVERSICOLOR SUPERTEXTA}

Due to high demand by gourmet restaurants and the unfounded belief that the small abalone has a tonic effect, especially for eye disease, the price of small abalone remains the highest among the species cultured in Taiwan. Seventeen years ago, small abalones caught from the littoral zone of rocky shores were stocked to wait for better market price. For a long time, there was no progress in pond culture, because of the shortage of seed and the lack of rearing techniques. Only recently, seed production and culture methods have been developed and practiced in commercial farms (Chen and Yang, 1979). The soaring demands of seed abalone for pond culture are thus satisfactorily met, and the pond area and the total annual production have increased very rapidly. Small abalone production was only 38 metric tons in 1976, but increased to 178 metric tons in 1977 with the highest yield in 1981 (Fig. 1). Most of the production since 1977 was mainly contributed by pond culture, and fishing in natural waters has become unimportant.

Abalones of 5.9-7.0 cm in shell length with fully matured gonads are selected for use as spawners. The seawater used should be UV irradiated and the spawners should be exposed to air for more than half an hour before commencing. Thermal shock together with the above-mentioned treatments usually yields the best results in induced spawning. In the golden season of breeding, simply increasing the temperature by $1^{\circ} \mathrm{C}$ per hour for $4 \mathrm{~h}$ and then decreasing by $4^{\circ} \mathrm{C}$ to the original temperature in $3 \mathrm{~h}$ has been found to be most effective. Newly laid eggs should be collected and fertilized within $1 \mathrm{~h}$ after spawning; delayed fertilization could result in a low percentage of larval 


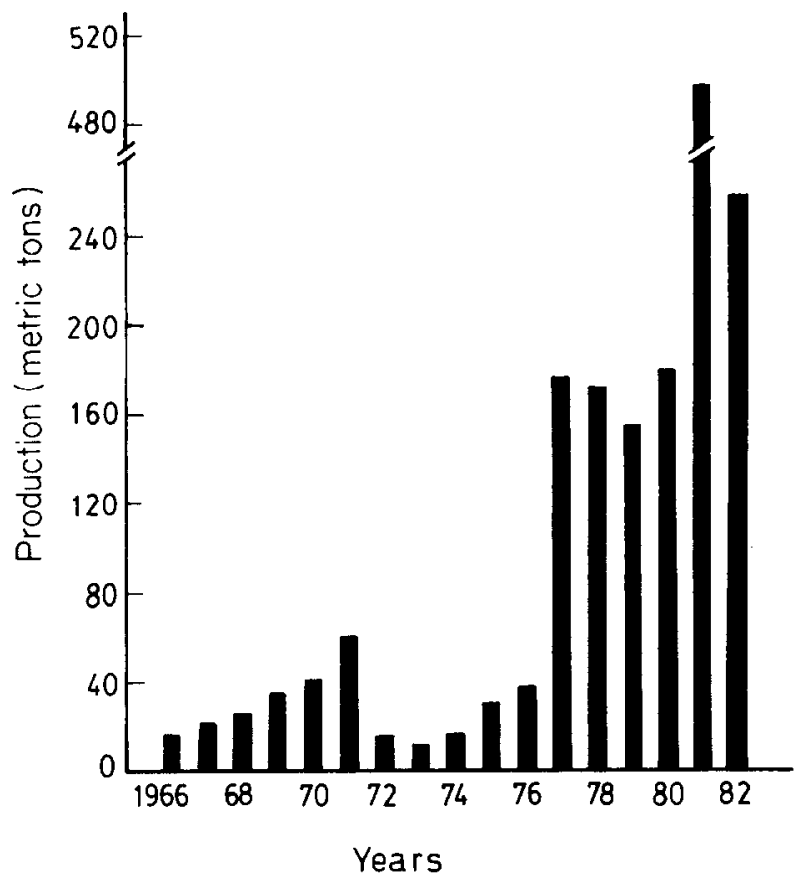

Fig. 1. Total yearly production of market-sized small abaione Haliotis diversicolor in Taiwan.

survival. Sperm concentration should be kept as low as 20,000 per milliliter to obtain a higher hatching percentage. Increasing the number of washings of the fertilized egg is expected to increase the hatching percentage. It is better to continue washing the fertilized eggs until hatching.

Although the breeding season occurs in 5 months during the winter with seawater temperatures between 20 and $26^{\circ} \mathrm{C}$, the optimal period for propagation should be in October and November at water temperatures of 22 $24^{\circ} \mathrm{C}$, according synchronous metamorphosis, less abnormality, and easier handling. In these 2 months, owing to less diurnal change of water temperature, swimming trochophores and veligers could be directly moved to outdoor seed rearing tanks for setting and for further growth to $5 \mathrm{~mm}$ in size. Otherwise, they should first be allowed to settle in indoor setting tanks and then moved to the outside after 1 week. Setting has been found to be heavier in the latter than in the former case, but higher survival and better growth are always encountered in the former case. Most commercial hatcheries nowadays perform induced spawning and larval setting only during these 2 months.

It is well known that many internal and external factors can influence the growth of abalones (Cox, 1958). Temperature, salinity, and food supply are considered to be the most important factors. In salinity of 32 parts per thousand, which is optimal for newly settled spat, the most suitable temperature range for the growth of spat is $22-27^{\circ} \mathrm{C}$. When abalone seed reach the juvenile stage of $10-20 \mathrm{~mm}$ in shell length, the animals prefer higher temperature and have more rapid growth at temperatures from $24-30^{\circ} \mathrm{C}$ (Fig. 
2). In addition, some juveniles and subadults have been reared and acclimatized to $33^{\circ} \mathrm{C}$ for a period of time and no disease or growth retardation has been found. Therefore, the bigger the abalone, the higher the optimal temperature. As a result, experiments are in progress to culture this species in Southern Taiwan, where water temperature in the summer is usually as high as $32^{\circ} \mathrm{C}$, and the preliminary results are surprisingly satisfactory.

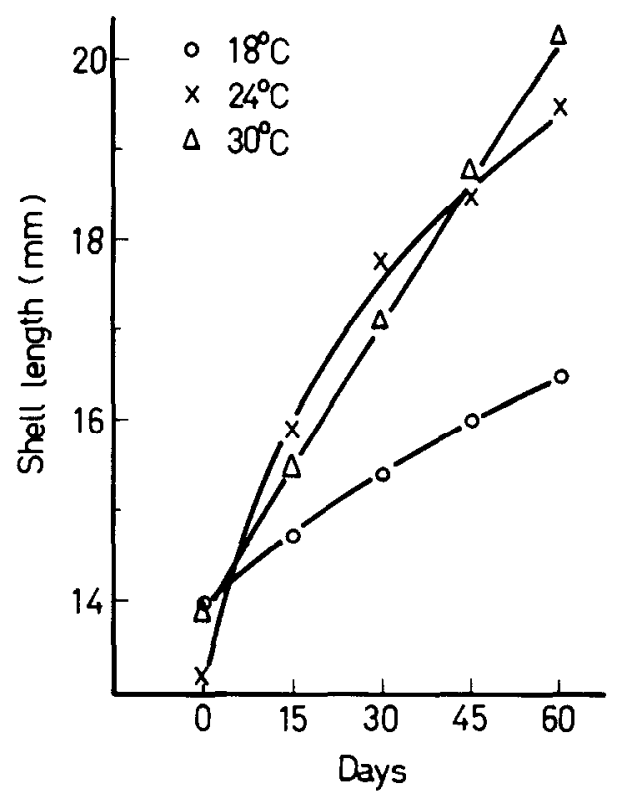

Fig. 2. Growth of juvenile abalones at three different temperatures in 35 parts per thousand salinity for 60 days.

The small abalone is a stenohaline species and is therefore markedly affected by changing salinities. The spat have higher tolerance to changing salinity than the embryos. Salinities in the range of 32-35 parts per thousand are considered optimal for survival of embryos and spat. A salinity range of 30-35 parts per thousand should be maintained to ensure fast growth of juvenile abalone (Fig. 3).

Studies of feeding habits show that abalones like to feed on the soft part of algae (Tunbridge, 1967; Tenore, 1976). They prefer Ulva to Gracilaria (Chiang and Lai, 1972) but the growth rate is faster in abalone fed with Gracilaria than in those fed with Ulva (Fig. 4). Although many species of seaweed could be used as feed, only Gracilaria meets the requirements of ample supply and low price. Therefore, almost all the abalone farms use Gracilaria as the main feed.

Improvements on rearing environments have greatly increased the growth of small abalones. Formerly, enclosed ponds were built with concrete roofs and a limited change of seawater, but it has now been recognized that rearing ponds should be open with a strong exchange of seawater and stocked at low density (250 individuals per square meter). As shown in Fig. 5, the time for the 


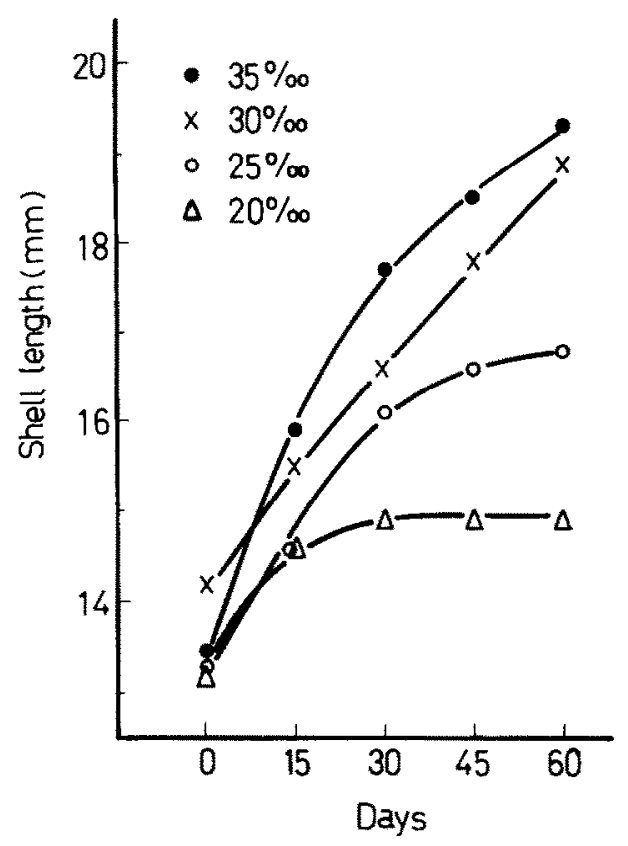

Fig. 3. Growth of juvenile abalones in four different salinities at $26^{\circ} \mathrm{C}$ for 60 days.

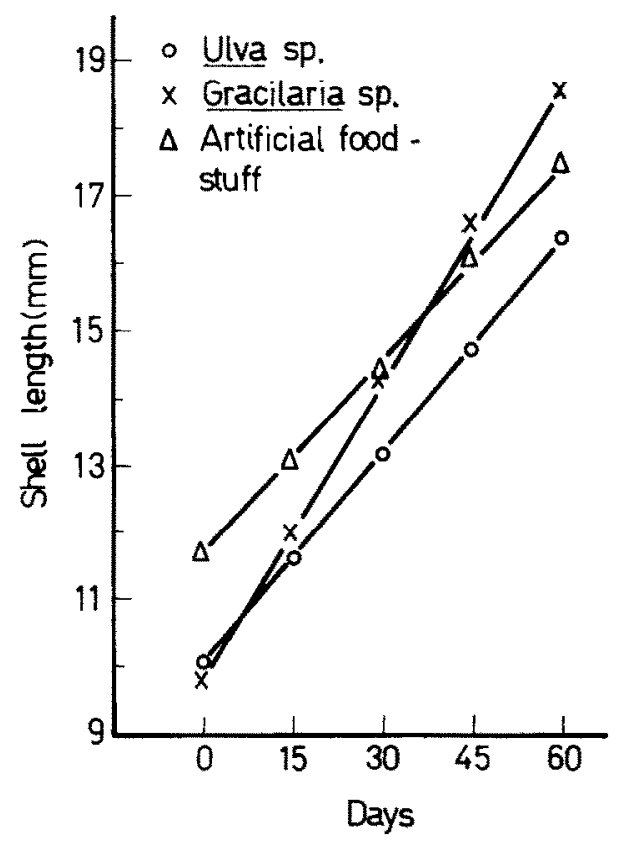

Fig. 4. Growth in shell length of juvenile abalones fed with different feeds for 60 days. 


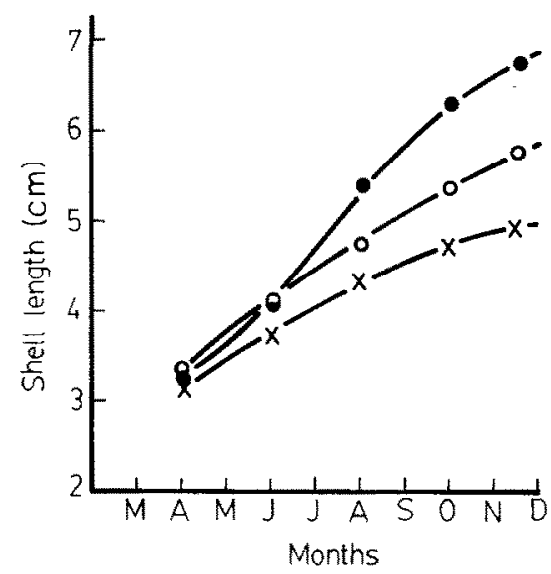

Fig. 5. Growth of abalones under different rearing conditions. X, Nearly enclosed pond; $O$, open pond with high stocking density; $\bullet$, open pond with low stocking density.

juvenile to reach a certain size takes 6 months in the enclosed pond, whereas it requires only 4 months in the open pond. Similar results have also been obtained at two different stocking densities. Presently, juveniles of less than 15 $\mathrm{mm}$ in shell length are stocked at a density of 2,500 per square meter and still show fairly good growth. When they grow to market size, 250 per square meter would be the optimal stocking rate for faster growth, stocking rates as high as 750 per square meter are always accompanied by detrimental effects.

Water quality of the pond also exerts an important effect on abalone growth. High hydrogen sulfide concentration and low dissolved oxygen concentration are usually detected in the rearing pond, owing to the decomposition of organic matter and respiration of organisms. Juvenile abalones are very sensitive to the toxicity of hydrogen sulfide; they survive for $48 \mathrm{~h}$ in $0.5 \mathrm{ppm}$ and only $16 \mathrm{~h}$ in $1.5 \mathrm{ppm} \mathrm{H} \mathrm{H}_{2} \mathrm{~S}$ (Chiu, 1981). A concentration as low as $0.05 \mathrm{ppm} \mathrm{H}_{2} \mathrm{~S}$ could still retard the growth of juveniles. In addition, the critical oxygen level needed for normal life for abalones is above $4 \mathrm{ppm} \mathrm{O}_{2}$ (Jan, 1980). Therefore, regular cleaning of bottom residue along with good seawater exchange to maintain good water quality is the first requirement for successful pond rearing.

Provided with optimal conditions, growth of spat to market size is so fast that they reach $4.3 \mathrm{~cm}$ after 1 year in pond culture and $6.9 \mathrm{~cm}$ after 2 years (Fig. 6), whereas they reach only 3.9 and $5.4 \mathrm{~cm}$ respectively in natural coast waters (Peon, 1980). Harvesting of market-size abalones begins 6 months after stocking the juveniles and is carried out intermittently whenever the price is good. Annual yield as high as $30 \mathrm{~kg} / 10 \mathrm{~m}^{2}$ has been reported from most of the farms in Taiwan (Chen, 1981). For further improvement, studies of selective breeding and hybridization with other abalone species are being made in order to produce new strains of abalone that have better tolerance to changing environments and faster growth. At present, the possibility of cage culture in coastal waters is also under consideration.

No serious disease has been noticed in pond culture, but young abalones 


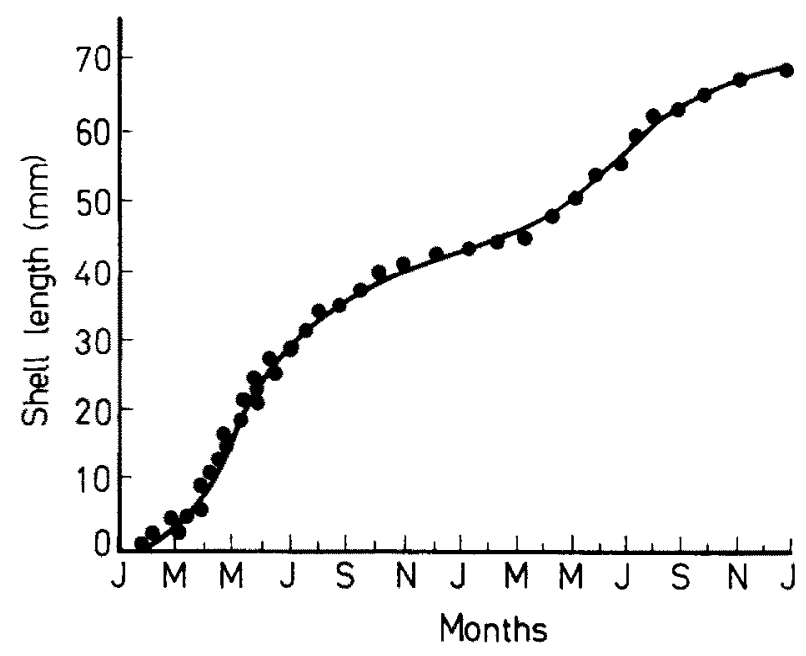

Fig. 6. Monthly growth curve of small abalones cultured in grow-out ponds.

with the shell split along the respiratory pores are not uncommon. This may result from injury of the mantle incurred when the seed are carelessly brushed off the corrugated sheets (Table I). Therefore, anesthetic drugs and thermal shock instead of brushing should be used to avoid injury. Most abalones produced are consumed domestically. There does not seem to be any possibility for export because of the high price in the domestic market ( $\$ 40$ per kilogram).

\section{TABLE I}

Percentage of abnormal shells induced by the injured mantle after 30 days' cultivation

\begin{tabular}{lcc}
\hline Treatment & Healthy & Injured \\
\hline Abnormal shells $(\%)$ & 0 & 26 \\
\hline
\end{tabular}

There are still some unsolved problems in relation to the further development of abalone culture, such as limited area of rocky shores, regulation of use of intertidal land, increasing industrial pollution, supplies of healthy seed, control of diseases and predators, improving pond conditions, and introduction of other species. In order to solve these problems, effort should be made to develop improved culture techniques on the basis of scientific research and to solve the social and economic restraints.

\section{HARD CLAM, MERETRIX LUSORIA}

Hard clams, native to Japan, were introduced into Taiwan five decades ago and have spread widely on many sandy beaches and estuaries. They are mainly found along the western coast of Taiwan, especially along the seashore from 
Tainan to Taichung. Expansion and production of clam culture before 1970 was limited by the seed supply and the primitive rearing techniques. Fish farmers collected seed clams ( 800 per kilogram) with an iron rake operated from a small craft in the estuary of Tansui River and sold them to the clam grower who reared them in ponds or sandy flats to a size of 50-60 per kilogram in about 1-1.5 years. Nursery ponds are similar to those for milkfish, having a water depth of $30-50 \mathrm{~cm}$ and being fertilized with chicken droppings. Harvesting was simply done with iron rakes, spades, or by hand. A person could harvest about $100 \mathrm{~kg}$ per day at most.

In 1971, fish farmers began to collect tiny clams of $0.5-1.0 \mathrm{~mm}$ in length with a slender nylon sieve from the sandy flats in tidal areas (Ting, 1981). The seed are white in color with one red spot inside or two narrow stripes on the shells, and can be distinguished from other bivalve clams. Usually, they are sold as a mixture of sand and clams to seed growers, who scatter them evenly in shallow nursery ponds of brackish water. A stocking rate ranging from 20 to 40 million per hectare is generally practiced. As it is not possible to buy the required quantities at a single time, bamboo sticks are inserted in nursery ponds to serve as markers indicating the time of stocking and size of seed for ease of sifting. Nursery pond salinity should be kept in the range of 20-30 parts per thousand, and pond water should be clear and light brown in color. The tiny seed do not grow and even die when the pond water is dark green or dark brown. In this case, the pond water should be partially changed and organic fertilizers applied. Harvesting at the size of 800-1000 per kilogram is made 6 or 7 months later and survival is usually quite good, not less than $60 \%$. Owing to this successful collection and nursery practice, the supply of clam seed is no longer a problem, resulting in the expansion of its culture area and consequently the increase of total production since 1972 (Fig. 7).

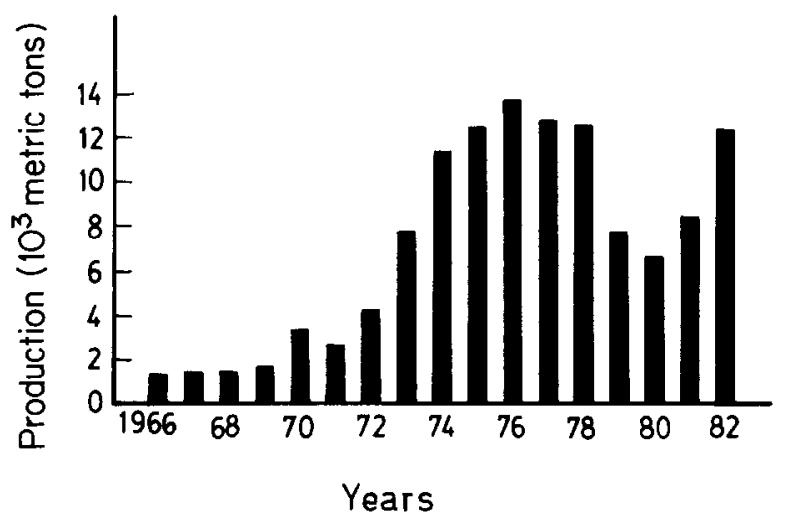

Fig. 7. Total yearly production of hard clam Meretrix lusoria in Taiwan.

A drop in annual production of hard clams was noticed from 1979 to 1981. This was due to the following reasons: First, the natural population of clam 
seed was scarce and catching enough for the nursery ponds became difficult. The amount of tiny clam seed collected was only one-fifth to one-thirtieth of the quantity captured in the previous years. Second, increased industrial pollution usually causes mass mortality of clams on the tidal flats from April to May. Because oysters cultured in the same area are more resistant to the polluted water than clams, many farmers planted oysters in order to avoid loss. Third, massive mortalities often occurred right after spawning in October at high stocking density under unfavorable conditions. Because of the abovementioned reasons, although the market price of clams was quite attractive, it did not seem to encourage the expansion of clam culture.

Rearing techniques and pond management have been improved and clam biology is also better understood in recent years. In nursery ponds, it used to take 7 months to grow to a size of 800 per kilogram with organic fertilizers, but now it needs only 4-6 months to reach the same size with artificial formulated feed. Similar improvement has also been obtained in grow-out ponds where harvest of market size (20-g) individuals could be made 6-8 months after planting instead of 1 year as before. In these ponds, fish meal, fish soluble as well as formulated feeds are also applied in addition to fertilization with rice bran, chicken droppings, and hog manure to accelerate the growth.

Clam seed grow best at 25 parts per thousand salinity (Fig. 8). Therefore, pond water was controlled near this range by frequent introduction of a mixture of fresh seawater and underground water. Growth of clam seed is more rapid at temperatures of $23-28^{\circ} \mathrm{C}$ than at $18^{\circ} \mathrm{C}$ (Fig. 9). Thus, stocking of clam seed is mostly done in August and September or in April. There is practically no growth in winter when the water temperature is low. Adult clams are very tolerant of high temperature, they show no ill effects even up to $37^{\circ} \mathrm{C}$. Stocking rate varies, but generally in one hectare $1000-1200 \mathrm{~kg}$ of clam seed (of size 800 per kilogram) are considered to be optimal in grow-out ponds for better growth and survival. In 1981, percentage survival in both nursery and grow-out ponds was as high as $80 \%$. Because of the high survival, fast growth, easy management, and attractive profit in pond culture of clams, many ponds formerly culturing milkfish, eel, and shrimp are now used for clams instead. Many tidal zone areas are being used as ponds for clam culture, and clam culture area increased by at least 1000 hectares in 1982. Thus, the total production of clams is bound to increase this year.

The method of harvesting is quite different from that formerly used. Powerful pumps were recently developed and have worked very well. An underwater plastic pipe connected to the pump is used to suck up the upper layer of the sandy bottom where tiny clams are abundant, and the mixture is then sieved with a nylon net on a small motor craft. In harvesting the clams of market size in grow-out ponds, a pump on a bamboo craft drawn by one person jets a strong water column through the connected plastic pipe to dig them out of the sand, and a bottom trawl net fitted with an iron rake follows to collect the clams. This practice is very effective, a team of two workers can harvest at least $600 \mathrm{~kg}$ of clams in 1 hour. The previously used spade and rake are no longer employed.

Because of the heavy demand and diminishing natural supply of seed clams, 


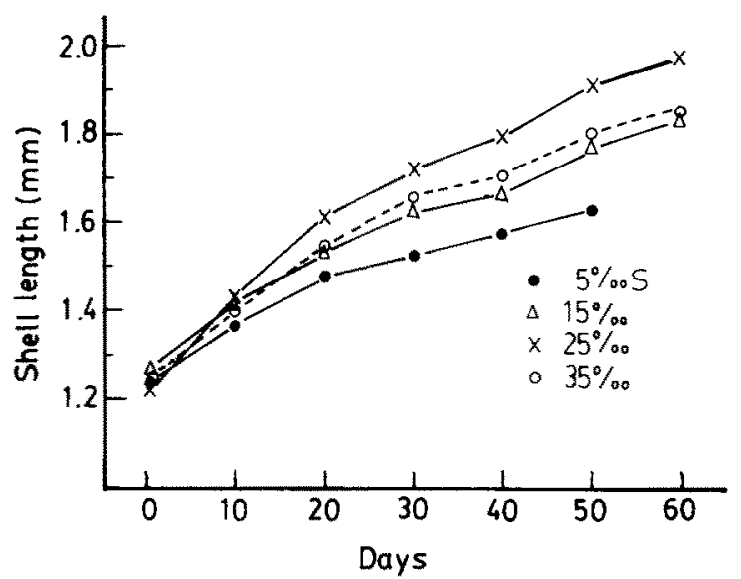

Fig. 8. Growth of hard clam seed reared in different salinities at $28^{\circ} \mathrm{C}$.

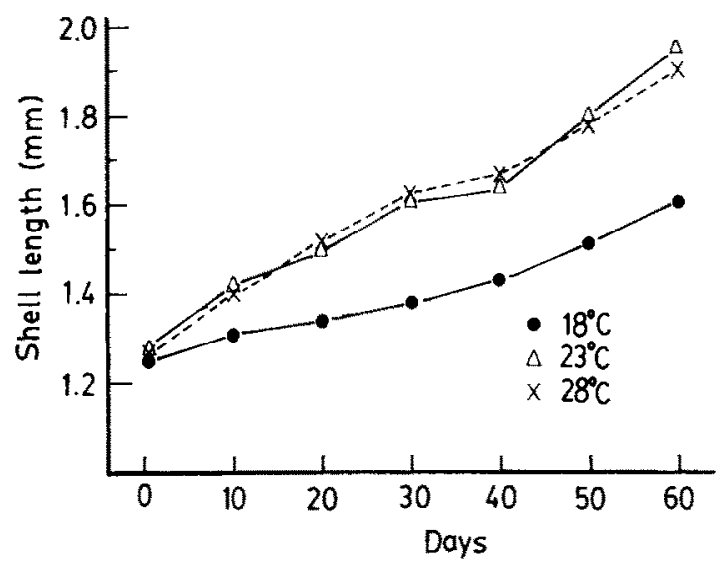

Fig. 9. Growth of hard clam seed reared at different temperatures in 15 parts per thousand salinity.

success has been achieved recently in the artificial propagation of hard clams in Taiwan (Chen and Lyuu, 1982). There are two breeding seasons, one in spring and the other in autumn. Sex of spawners can easily be distinguished by their external features and the shape of the escutcheon. Induced spawning is generally effected by the combination of air exposure, followed by raising the water temperature. In some cases, an addition of gonad extract can be very helpful. Males are separately induced in order to control the concentration of sperm during fertilization. The optimal salinity and temperature for survival and larval development are in the range of 15-20 parts per thousand and 23$28^{\circ} \mathrm{C}$ respectively (Fig. 10 and Table II). The best food organism for the swimming larvae is Isochrysis, followed by Platymonas, green algae with thick cell walls are not recommended. It takes the swimming larvae 7-10 days before 
setting under the most favorable conditions, otherwise as long as 20 days may be required. Straight-hinged larvae are also raised to the setting stage in some cases by feeding them with yeast or the purple nonsulfur bacteria Rhodospirillum, but survival is poor. Growth of swimming larvae and newly settled seed fed on Isochrysis in the hatchery is encouraging (Fig. 11); they could be treated as tiny seed after slightly more than 1 month. At present, there are 15 commercial clam hatcheries, production of 30 million tiny seed from one hatchery is not uncommon. It is predicted that with this new development the total clam production may be greatly increased in the next few years.

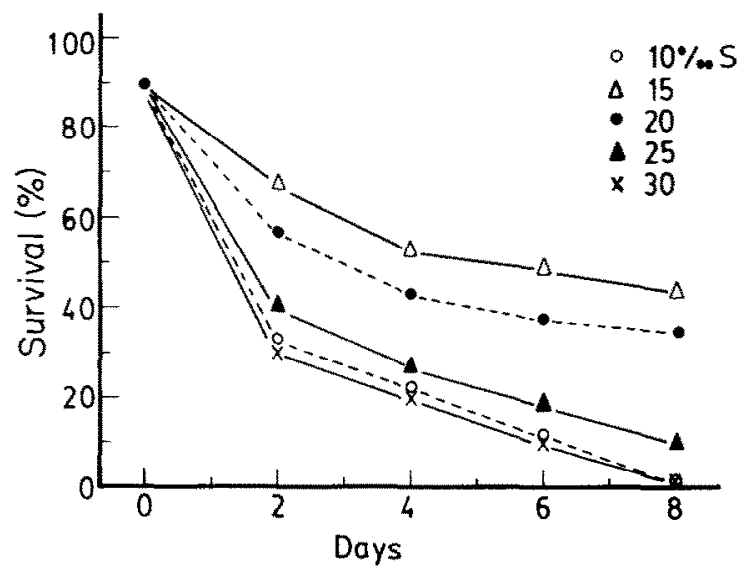

Fig. 10. Percentage survival of swimming larvae of hard clams reared in different salinities.

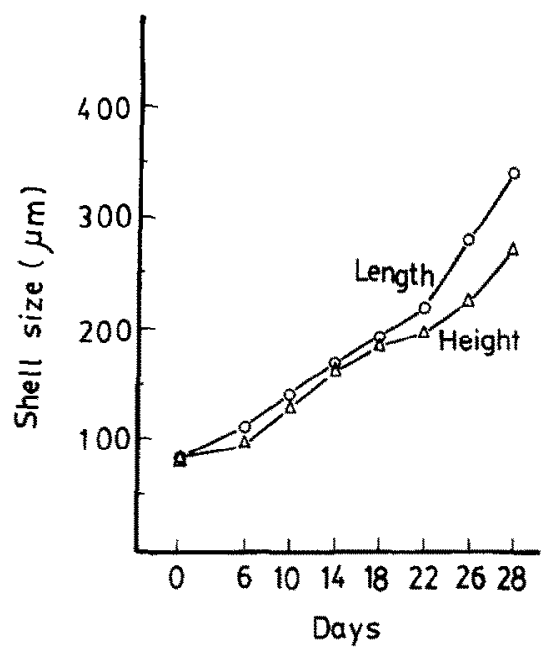

Fig. 11. Larval growth of hard clams fed with Isochrysis at $23^{\circ} \mathrm{C}$. 
TABLE II

Time in hours needed to reach different embryonic stages in 15 parts per thousand salinity at various temperatures ${ }^{\mathrm{a}}$

\begin{tabular}{lccc}
\hline \multicolumn{1}{c}{ Stage } & \multicolumn{3}{c}{ Water temperature $\left({ }^{\circ} \mathrm{C}\right)$} \\
\cline { 2 - 4 } & 18 & 23 & 28 \\
\hline Appearance of & & & \\
polar body & 1.42 & 0.23 & 0.63 \\
2-Cell stage & $*$ & 1.43 & 1.25 \\
4-Cell stage & $*$ & 2.08 & 1.67 \\
8-Cell stage & $*$ & 2.83 & 2.0 \\
16-Cell stage & $*$ & 3.67 & 2.42 \\
Morula stage & $*$ & 5.33 & 3.17 \\
Trochophore & & & \\
Stage & $*$ & 8.25 & 4.67 \\
D stage & $*$ & 22.0 & 15.0 \\
Settled stage & $*$ & 408.0 & 168.0 \\
\hline
\end{tabular}

${ }^{a}$ An asterisk indicates that embryonic development did not proceed under this condition.

As mentioned, foreign markets did not seem possible in the previous years because of the high local price ( $\$ 2.5-4$ per kilogram). Increased production this year has resulted in a decreased market price of $\$ 1.25-2.50$ per kilogram. Thus, there is still potential for the export market, especially for the large-sized clam, which the foreign market prefers.

\section{OTHER SPECIES OF MOLLUSCS}

\section{Freshwater clam, Corbicula fluminea}

Considered a nuisance species in other countries, this species is probably intensively cultured only in Taiwan, and is considered the most successful cultured item among molluscs. Asian people are quite fond of them. They are eaten either cooked or raw and are believed to have medicinal value for treatment of liver disease.

Culture practice has been studied and described previously (Chen, 1976), but enormous development and improvement have been achieved in the last few years. As can be seen in Fig. 12, there has been a great increase in production since 1976. Annual production per hectare in pond culture averages 10 to 15 metric tons with a maximum of 30 metric tons. The color in the outer surface of the shell usually becomes black on the loamy bottom as they grow older, but due to the continuous selection of the greenish-yellow strain in some ponds, now the shells always maintain the same color regardless of the bottom type and age of the pond.

A few years ago, soybean meal, rice bran, chicken droppings, and inorganic fertilizers were often applied to the pond. Because of the decomposition of this 


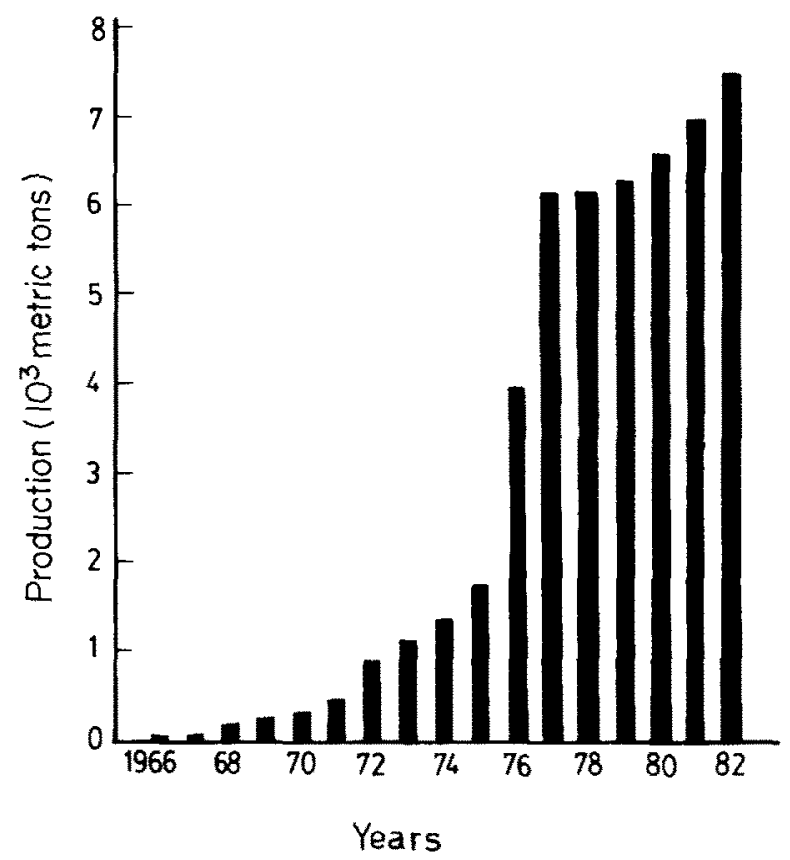

Fig. 12. Total yearly production of freshwater clam Corbicula fluminea in Taiwan.

organic matter, the clams often died of oxygen depletion and toxic substances, especially in the summer season.

Presently, nearby fertile water from a duck cum fish pond is introduced along with underground water to enrich the pond, to elevate the survival rate, and to save the expense of fertilizers. A survival rate as high as $80 \%$ is usually obtained. Intermediate harvesting and periodic restocking at regular intervals are also practiced in order to utilize the space and fertility. Freshwater snails, Cerithidea sp., which compete for food with the clams, are found on the bottom. They could easily and regularly be removed by an iron plate attached to a net. The harvesting method for market-size Corbicula is similar to that used for hard clams; with a pump, a team of two persons can collect 3-4 metric tons in $8 \mathrm{~h}$ whereas only $600-800 \mathrm{~kg}$ were collected with the old-fashioned iron rake.

Seed of freshwater clams can be found in the estuarine areas where the water is slightly brackish, or on some occasions they propagate spontaneously in newly built ponds. But the natural supply does not meet the great demand and expansion of new ponds. The most important innovation in the culture of freshwater clams is that seed can be obtained in ponds all year round by proper pond management and control of water quality. Ponds used for continuous propagation purposes should meet the following requirements: water depth of $80-100 \mathrm{~cm}$, light greenish-yellow or fairly transparent, mildly continuous flowing current caused by introduction of the mixture of fertile water and underground water, maintaining the pond water slightly brackish and at a 
temperature of $28-30^{\circ} \mathrm{C}$. Otherwise clam seed could only be harvested in the autumn. With the above-mentioned treatments the annual production of seed clam per hectare amounts to 100 metric tons at the size of 15,000 per kilogram.

Rearing clams at high densities in water that is not frequently changed results in thin-shelled individuals which are not desirable, for they will be crushed during transportation. Another common problem, especially in aged ponds is peeling-off of the shell in the umbo area. Although the cause has not been fully understood, application of calcium chloride and increasing fertility and $\mathrm{pH}$ value may slowly cure this disease.

\section{Pacific oyster, Crassostrea gigas}

Oyster culture in the estuaries, tidal zone, and inshore waters along the west coast of Taiwan has become the most important activity in molluscan culture (Li and Yuan, 1981). This species is also farmed in other Pacific regions and there are many studies relating to its culture (Koganezawa, 1978). Formerly, all oysters were cultivated on tidal flats and bamboo or plastic sticks were used. Because of its low productivity, this method has diminished in importance and is now used only to a small extent. Now most oysters are grown off-bottom by the rack, raft, or long-line method. The rack method used for both adult and seed oyster production is used in the shallow-water tidal zone. Raft culture is practiced in calm and protected sea areas for production of adult oysters. The long-line method, a better way of resisting rough sea, has spread to the deeper waters of exposed areas. The off-bottom method is increasing in importance and popularity, because of increasing pollution in the inshore water and limited littoral area. Steady increase in total annual production since 1964 has been noted (Fig. 13), owing simply to the extended areas where off-bottom methods are employed.

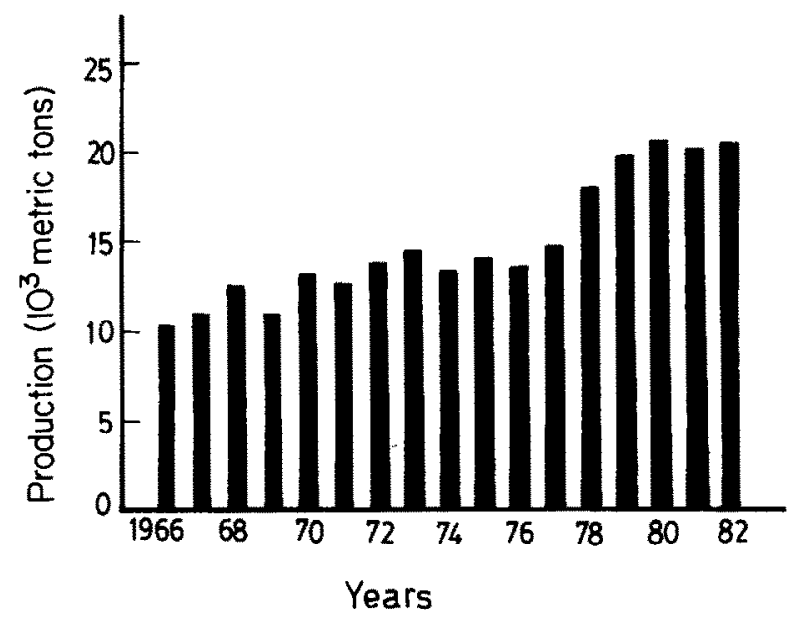

Fig. 13. Total yearly production of oyster Crassostrea gigas in Taiwan. 
Cultured oysters are usually harvested when they exceed $5 \mathrm{~cm}$ in shell length. It takes about 4 months to reach this market size, and the oysters are consumed almost entirely domestically. There is no way of opening a foreign market, because it is rather difficult to produce oysters of large size and good quality in Taiwan. High summer temperatures inhibit the growth of oysters and cause them to spawn very often. Once they have spawned, the meat is of poor quality.

Collection of spat was not possible in some areas where unfavorable conditions exist. Many formerly good areas are no longer suitable for spat collection because of increased silting and industrial pollution, which prevent the swimming larvae from settling on the collectors (Liang, 1981). An effort is being made to study the propagation in hatcheries to secure a supply of spat for culture. This will be the most important work for the next few years.

Three predators, the oyster drill, Purpura sp. (Lin and Hus, 1979); flatworm Stylochus sp. (Shu and Lin, 1980); and stone crabs, Thalamita sp. prey heavily on oysters; oyster mortality of $20-70 \%$ is usually found. Until now, in spite of many trials, there is no satisfactory way of removing or killing these predators chemically or mechanically (Hwang and Huang, 1971).

In recent years, mass mortality of oysters has occurred along the western coast in April and May and in October and December. The cause of mortality is not understood, but industrial pollution, high density of planting, rapidly changing weather, and bacterial disease may have contributed synergistically to this loss. Studies are in progress to find the cause of these mortalities and a method of prevention.

\section{Cockle, Anadara granosa}

Cockle is a highly priced species because of its scarcity and its red meat. It can be found on mud flats inside estuary or shore areas where the water salinity is from 15 to 25 parts per thousand. They are very abundant in Malaysia, Thailand, and Korea, but their production in Taiwan is insufficient to meet the local demand. Thus, every year great quantities of cockles are imported from Korea for temporary stocking and held to get a good price. The culture practice is similar to that for hard clams, with the exception of the harvesting which is done by iron rake and hand. The total annual production in Taiwan has decreased dramatically; 145 metric tons in 1970, 74 tons in 1975, and 7 tons in 1980, and no more than 3 tons are predicted for 1982. The reasons for this decline are overfishing of wild adult cockles, short supply of seed, and probably industrial pollution. Therfore, efforts should be made to study artificial propagation and hatchery techniques.

\section{Purple clam, Soletellina diphos}

This species is not very popular because of its scarcity, but the price ranks second among the molluscs cultured in Taiwan. Total annual production in recent years has increased to about 140 metric tons which is double or triple the total amounts produced in the years 1973-1977. Formerly, most of the purple clams were captured from the natural population in the tidal zone of sandy beach where water salinity is in the range of 15-30 parts per thousand. 
Now they are planted in these areas or in combination with hard clams or short-necked clams in ponds as a supplementary product. The growth rate is as rapid as that of the hard clam, but they burrow into the sand to a depth of 30$60 \mathrm{~cm}$, thus making the harvest more difficult; a more powerful pump is used to catch this deeply burrowed species. A weight of $20 \mathrm{~g}$ each is the favored size in the market. Transportation of the seed over long distances should be avoided, because they do not stand air exposure for more than half a day.

Although seed collection of purple clams can be done year-round, the supply is still far from sufficient. This species possesses great potential and its culture deserves further expansion, if the problem of supply of seed can be solved. Therefore, studies on the propagation of this mollusc should be of first priority in the culture practice of the species.

\section{Short-necked clam, Comphina veneriforms}

This small bivalve, only half the size of the hard clam, is mainly cultured on sandy beach of the tidal zone in Chung Hwa and Chia Yi counties. They prefer normal seawater of 30-35 parts per thousand salinity to brackish water, thus it is not necessary to rear them in nursery and grow-out ponds. Seed are captured from the sandy shore at a size of 5,000 per kilogram or obtained by separation from hard clam seed during sifting in nursery ponds (at 17,000 per kilogram in size) from January to April. Clam farmers generally set up two plastic nets to surround the culture area. Otherwise they will escape with the tidal current when conditions are unfavorable, or they will be preyed on by crabs and octopuses. Market size of about 120-160 per kilogram could be obtained in about 10 months. The harvesting method is similar to that for hard clams, but sometimes iron rakes attached to nets are also employed. The growth rate is slightly slower than that of hard clams. Total annual production has increased markedly since 1970 (Fig. 14) and could be further increased if the supply of wild seed is enough or seed can be produced in the hatchery in large quantities. In view of the successful propagation of the hard clam, there should not be much difficulty with the short-necked clam.

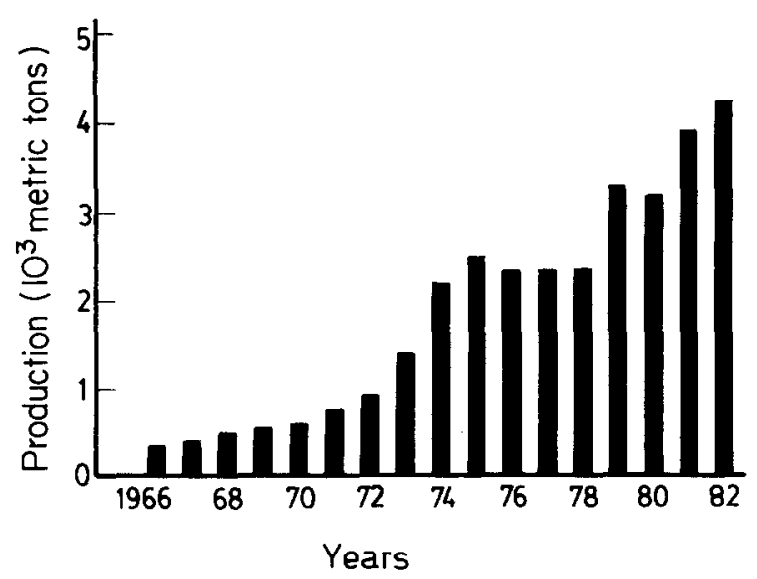

Fig. 14. Total yearly production of short-necked clam Comphina veneriforms in Taiwan. 


\section{ACKNOWLEDGMENTS}

Many thanks are due to Dr. T.P. Chen, Taiwan Fisheries Consultants, Inc. for kindly reading the manuscript.

\section{REFERENCES}

Chen, H.C., 1981. Studies on the aquaculture of small abalone, Haliotis diversicolor in Taiwan. In: ROC-Japan Symposium on Mariculture, 14 - 15 December 1981, Taipei, Taiwan (unpubl.), $35 \mathrm{pp}$.

Chen, H.C. and Lyuu, R.Y., 1982. Studies on the artificial propagation of the hard clam, Meretrix lusoria. 1. Sex distinction. J. Mar. Sci., 27:1:8.

Chen, H.C. and Yang, H.H., 1979. Artificial propagation of the abalone, Haliotis diversicolor supertex. China Fisheries Monthly, 314:3-9. (in Chinese, with English abstract).

Chen, T.P., 1976. Aquaculture practices in Taiwan, Fishing News Books Limited, Surrey, England, $161 \mathrm{pp}$.

Chiang, Y.M. and Lai, C.F., 1972. Studies on the feeding habit of small abalone. China Fisheries Monthly, 284:6-7 (in Chinese, with English abstract).

Chiu, C.C., 1981. Biological studies on the propagation and larval rearing of abalone, Haliotis diversicolor. Master Thesis, National Taiwan University, Taiwan, $53 \mathrm{pp}$.

Cox, K.W., 1958. Summary report of abalone investigation. Calif. Dept. Fish and Game, Typed Report, 4 pp.

Hwang, Y.W. and Huang, S.C., 1971. Biology and control of the Taiwan oyster drill. Thais tumulosa. China Med. Coll. Ann. Bull., 2:1-44.

Jan. R.O., 1980. Studies on the oxygen consumption of small abalone, Haliotis diversicolor. Master Thesis, National Taiwan University, Taiwan, $72 \mathrm{pp}$.

Jeng, S.S. and Chen, S.J., 1975. Acute toxicity of Po-Tzu river water and the mass mortality of cultured shellfish. J. Fish. Soc. Taiwan, 4:73-83.

Koganezawa, A., 1978. The status of Pacific oyster culture in Japan. In: Advances in Aquaculture, 332-337. Fishing New Books Limited, Surrey, England.

Li, Y.P. and Yuan, P.W., 1981. Status of aquaculture in Taiwan. In: Proceedings of ROC-US Cooperative Science Siminar on Fish Dieseases. NSC Symposium, 3:1-6.

Liang, M.H., 1981. Growth and setting of cultured oyster in Putai Bay. Master Thesis, National Taiwan University, Taiwan, $56 \mathrm{pp}$.

Lin, Y.S. and Hsu, C.T., 1979. Feeding, reproduction and distribution of oyster drill, Purpura clavigera. Bull. Inst. Zool., Academic Sinica, 18(1):21-27.

Peon, S.C., 1980. Studies on the age and growth of Haliotis diversicolor in Hua Lien. Master Thesis, National Taiwan University, Taiwan, $55 \mathrm{pp}$.

Shu, J.U. and Lin, Y.S., 1980. Biological studies on the oyster predator, Stylochus inimicus. CAPD Fisheries Series, 3:39-51.

Taiwan Fisheries Bureau, 1982. Taiwan Fisheries Yearbook. Taiwan Fisheries Bureau, $173 \mathrm{pp}$.

Tenore, K.R., 1976. Food chain dynamics of abalone in a polyculture system. Aquaculture, $8: 23-27$.

Ting, Y.Y., 1981. Shellfish culture in Taiwan. In: ROC-Japan Symposium on Mariculture, 1415 December 1981, Taipei, Taiwan (unpubl.), 19 pp.

Tunbridge, B.R., 1967. Feeding habits of paua. Fish Rept., New Zealand Marine Dept., 20:118. 